\title{
Relevant aspects of golden retriever muscular dystrophy for the study of Duchenne muscular dystrophy in humans
}

\author{
Julieta Rodini Engrácia de Moraes $^{1 *}$ Lygia Maria Mouri Malvestio $^{2}$ Isabela Mancini Martins ${ }^{1}$ \\ Patrícia Regina Erdmann Mosko ${ }^{3}$ Jair Rodini Engracia Filho ${ }^{3}$ Flávio Ruas de Moraes ${ }^{1}$
}

${ }^{1}$ Faculdade de Ciências Agrárias e Veterinárias (FCAV), Universidade Estadual Paulista (UNESP), 14884-900, Jaboticabal, SP, Brasil. E-mail: julietaengracia@gmail.com. "Corresponding author.

${ }^{2}$ Escola de Medicina Veterinária, Faculdade Meridional (IMED), Passo Fundo, RS, Brasil.

${ }^{3}$ Programa de Pós-graduação em Ciência Animal (PPGCA), Pontifícia Universidade Católica do Paraná (PUC-PR), Curitiba, PR, Brasil.

\begin{abstract}
Golden Retriever muscular dystrophy (GRMD) is the most representative model for studying Duchenne muscular dystrophy (DMD) in humans, owing its phenotypic expression. DMD is a recessive disorder linked to the X chromosome in which the loss of dystrophin induces progressive weakness and degeneration of the skeletal and cardiac muscles, which lead to replacement by connective and adipose tissues. Onset of clinical signs occurs between 2 and 5 years of age, and many patients die from heart or respiratory failure. The main studies concerning dystrophic Golden Retrievers (DGR) sought to elucidate the pathophysiology of the disease and its clinical implications to develop therapies and alternative treatments to improve the quality of life and increase longevity of DMD patients. This review presents an overview of relevant contributions of the DGR model for elucidating DMD in humans.

Key words: Duchenne muscular dystrophy, animal model, dystrophic Golden Retriever.
\end{abstract}

Aspectos relevantes da distrofia muscular do Golden Retriever para o estudo da distrofia muscular de Duchenne em humanos

RESUMO: A distrofia muscular do Golden Retriever (DMGR) é o modelo mais representativo para o estudo da distrofia muscular de Duchenne (DMD) em humanos devido a sua expressão fenotípica. A DMD é uma desordem genética recessiva ligada ao cromossomo X onde a perda da distrofina induz fraqueza progressiva e degeneração do músculo esquelético e cardíaco conduzindo a substituição do músculo por tecido conjuntivo e adiposo. O início da doença ocorre entre 2 e 5 anos de idade e muitos pacientes morrem por insuficiência cardíaca ou respiratória. Os principais estudos realizados no Golden Retriever distrófico (GRD) buscam elucidar a fisiopatogenia da doença e suas implicações clínicas na tentativa de testar terapias e tratamentos alternativos para melhoria da qualidade de vida do paciente distrófico e aumentar sua longevidade. Esta revisão apresenta uma visão geral sobre relevante contribuição do modelo GRD para elucidar a DMD em humanos.

Palavras-chave: Distrofia muscular de Duchenne, modelo animal, Golden Retriever distrófico.

\section{INTRODUCTION}

Duchenne muscular dystrophy in humans is a recessive disorder linked to the $\mathrm{X}$ chromosome that is characterized by a mutation of the dystrophin gene. It manifests as progressive degeneration and necrosis of skeletal and cardiac muscles, with subsequent replacement by connective and adipose tissue, leading to generalized muscle weakness (VALENTINE et al., 1989; COLLINS \& MORGAN, 2003; BANKS \& CHAMBERLAIN, 2008; KASPAR et al., 2009; NAKAMURA \& TAKEDA 2011).

Sex-linked muscular dystrophy associated with dystrophin deficiency has also been reported in some breeds of dogs, and is best seen in the Golden Retriever breed, as a condition known as golden retriever muscular dystrophy (GRMD) (BERGMAN et al., 2002). This is the most common form of muscular dystrophy in dogs (SHELTON et al., 2001). In the case of a dystrophic golden retriever dog (DGR), the mating of heterozygous female dogs with affected male dogs produces normal male dogs, heterozygous female dogs, and affected male and female dogs (VALENTINE et al., 1988). GRMD colonies were established in the United States, Australia, Italy, France and Brazil (NGUYEN et al., 2002). Several experimental models of DMD have been developed in animals. Animal models genetically homologous to DMD-such as the mouse 
with a mutation on the $\mathrm{X}$ chromosome $(\mathrm{mdx})$, and the cat with hypertrophic feline muscular dystrophypresent moderate clinical characteristics and little or no endomysial fibrosis (BULFIELD et al., 1984). However, GRMD is the most relevant animal model for the study of DMD, particularly considering its potential therapeutic approach (MIYAZATO et al., 2011b).

GRMD is similar to DMD in humans due to clinical and pathological characteristics, in which young adult dogs often die from respiratory or cardiac failure (VALENTINE et al., 1988). A high mortality rate is typically observed in the first two weeks of life (VALENTINE et al., 1988; VALENTINE \& COOPER, 1991; HOWELL et al., 1994).

Despite the considerable understanding of the pathophysiology, molecular basis, and therapeutic approaches of DMD, no effective treatment is available yet to halt the progression of the disease (ALLAMAND \& CAMPBELL, 2000; DECONINCK \& DAN, 2007; BANKS \& CHAMBERLAIN, 2008). In this sense, the use of an animal model, mainly a canine model, in DMD research continues to provide valuable clues in the elucidation of the pathogenesis and the development of new therapies (ALLAMAND \& CAMPBELL, 2000; COLLINS \& MORGAN, 2003; BANKS \& CHAMBERLAIN, 2008; NAKAMURA \& TAKEDA, 2011; MIYAZATO et al., 2011c; KORNEGAY et al., 2012). Different canine models of DMD have been reportedly used for studying the disease (COOPER et al., 1988; SHARP et al., 1992; SCHATZBERG et al., 1999; SHIMATSU et al., 2003; WALMSLEY et al., 2010). Golden retriever dog with muscular dystrophy is the main lineage studied and is the best characterized. This review presents an overview of DMD and the pathological, immunological and molecular studies that have involved the GRMD model, highlighting its contribution to a better understanding pathophysiology and morphofunctional expression of the disease.

\section{Current overview of Duchenne muscular dystrophy}

Duchenne muscular dystrophy (DMD), also called progressive muscular dystrophy, is a recessive $\mathrm{X}$-linked hereditary disorder. It results from changes in the short arm of the $\mathrm{X}$ chromosome in the $D M D$ gene of the xp21 region. This gene has 79 exons and encodes a protein called dystrophin (ZATZ, 2004). Thirty-eight relevant human mutation sites have been described (EMERY et al., 2015), and genetic mutations of any order (deletion, duplication, insertion or of point) (McGREEVY et al., 2015) can lead to the absence of dystrophin in the sarcoplasmic membrane of the muscle cells and cause its rupture, calcium influx and subsequent activation of endogenous protease with activation of inflammatory cascade, and consequent necrosis and replacement of muscle tissue by adipose and fibrous tissue (DILAYLA \& ABREU, 2015).

DMD is the most common muscular disorder in children, with phenotypic manifestation in male patients only. The incidence varies from 1:3,000 to 1:5,000 live births (McGREEVY et al., 2015). It manifests itself in early childhood, between 3 and 5 years of age, and is characterized by proximal muscle weakness and calf hypertrophy. Affected boys demonstrate delays in motor development; are easily fatigued; and have difficulty of running, jumping or standing up from the ground. Indeed, many of them have frequent falls or tip-toe walking. Typical associated posture is of lumbar lordosis and anserine gait (ZATZ, 2004). Less frequently, DMD causes a delay in language or overall development, or incidental findings of an increase in the serum levels of creatine kinase or transaminases when these investigations are performed for other reasons (JONES et al., 2003).

The course of the disease may lead to boys becoming wheelchair-bound between the ages of 8 and 12, the same age at which there is cardiac and respiratory compromise (JONES et al., 2003). At this time, the development of hypertrophic cardiomyopathy secondary to cardiac fibrosis also occurs. These patients often demonstrate persistent tachycardia, ventricular and atrial arrhythmias, premature ventricular complexes or sustained ventricular ectopic beats. Many patients are asymptomatic regarding cardiac dysfunction; however, because they are physically inactive (NIGRO et al., 1990). Respiratory dysfunction begins around the age of 10 years, with chronic respiratory failure presenting due to restrictive lung disease. Vital capacity reduces approximately $8 \%$ to $12 \%$ per year, and when it reaches 1 liter, the risk of death in the next one to two years is very high (PHILLIPS et al., 2001). Average life expectancy is considered to be 20 years, when the patient approaches death due to cardiorespiratory complications (JONES et al., 2003).

Several symptomatic therapies have been proposed, and the association of some of them may be necessary, depending on the condition of each patient. They extend from physiotherapy to the use of corticosteroids, and aim at delaying the progression of the disease and increasing the length and quality of patients life. However, new therapeutic strategies have been studied in the search for correction of the underlying cause and cure. These therapies are: (1) gene therapies, or the use of viral vectors, plasmid vectors, exon skipping and gene correction; (2) cell therapies 
(stem cells), or the use of embryonic stem cells and adult stem cells; (3) pharmacological therapies, or the use of stop codon read-through, absence of dystrophin (utrophin) compensation and muscle growth and regeneration stimulators (GUEDES, 2012); and, more recently, the especially promising technique of (4) genome editing, such as CRISPR (clustered regularly interspaced short palindromic repeats) and TALEN (transcription activator-like effector nucleases) (McGREEVY et al., 2015; KAISER, 2016).

\section{Dog as model of muscular dystrophy}

Canine model is one of the best phenocopies of DMD in humans, when compared with other study models (BOGDANOVICH et al., 2003; COLLINS \& MORGAN, 2003). Spontaneous mutations in the dystrophin-encoding gene, resulting in muscular dystrophy linked to the $\mathrm{X}$ chromosome, have been reported in several dog breeds (COLLINS \& MORGAN, 2003; SHELTON \& ENGVALL, 2005; NAKAMURA \& TAKEDA, 2011). Genetic mutations in the Golden Retriever, Rottweiler, German Shorthaired Pointer, Cavalier King Charles Spaniels, Beagle and Weimaraner breeds were described (COOPER et al., 1988; SHARP et al., 1992; SCHATZBERG et al., 1999; SHIMATSU et al., 2003; BALTZER et al., 2007; WALMSLEY et al., 2010). All canine models of DMD, type of mutation, and site of each dystrophin gene mutation are described in table 1.

Canine muscular dystrophy linked to the $\mathrm{X}$ chromosome is recognized and well-characterized in golden retriever dogs, where it occurs spontaneously (SHIMATSO et al., 2003). In Brazil, studies on genetics, clinic, pathology, molecular biology, and immunocytochemistry performed in the canine model have been useful in the evaluation of Duchenne muscular dystrophy in humans.

GRDM dogs have been extensively studied and have led to a better understanding of the condition for research on DMD in humans, especially in the experimental evaluation of new treatments in preclinical trials (COLLINS \& MORGAN, 2003; SHELTON \& ENGVALL, 2005; BANKS \& CHAMBERLAIN, 2008; SILVA et al., 2009; NAKAMURA \& TAKEDA, 2011). Both DMD and DGR present progressive clinical signs and severe myopathy with initial fiber necrosis and regeneration associated with connective tissue proliferation in the endomysium and perimysium (VALENTINE et al., 1990,; MIJAZATO et al., 2011b; KORNEGAY et al., 2012). Also, adult dogs have a body mass compatible with that of patients with DMD. Thus, DGR is indicated as an excellent model for studying the disease in humans (COOPER et al., 1988). Table 2 summarizes all the common characteristics of DMD and GRDM that show the benefits of using GRDM as an experimental model of the disease in humans.

\section{Course of the disease in the DGR dog}

GRMD is characterized by progressive muscle weakness and atrophy. These characteristics are similar to those of human DMD (NAKAMURA \& TAKEDA, 2011). Extremely high levels of creatine kinase (CK) are identified in the first days of life, with a peak at six to eight weeks after birth, even before clinical signs appear, suggesting that the onset of

Table 1 - Comparison table of the site and types of genetic mutations in dog models of DMD according to breed.

\begin{tabular}{|c|c|c|}
\hline Breed & Type of Mutation & Site of the Mutation \\
\hline Cavalier King Charles Spaniel (CKCS-MD) & \multirow{4}{*}{ Point mutation } & Intron 50 \\
\hline Golden Retriever (GRMD) & & Intron 6 \\
\hline Rottweiler & & Exon 52 \\
\hline Mixed Breed Golden Retriever- Beagle (CXMD) & & Intron 6 \\
\hline Cocker Spaniel & \multirow{4}{*}{ Deletion mutation } & Exon 65 \\
\hline Tibetan Terrier & & Exons 8-29 \\
\hline German Short-haired Pointer (GSHP) & & All the gene \\
\hline Mixed Breed Pembroke Welsh- Labrador Retriever (CKCS-MD) & & Exons $45-53$ \\
\hline Pembroke Welsh Corgi & \multirow{2}{*}{ Insert mutation } & Intron 13 \\
\hline Labrador Retriever & & Intron 19 \\
\hline Japanese Spitz & \multicolumn{2}{|l|}{ Chromosome inversion } \\
\hline Mixed Breed Labrador and Poodle & \multirow{2}{*}{ Not known } & \\
\hline Springer & & \\
\hline
\end{tabular}

(McGREEVY et al. 2015; DUAN et al., 2015). 
Table 2 - Summary of characteristics that show the benefits of using GRDM as an experimental model of DMD.

Features common to GRDM and DMD

\begin{tabular}{|c|c|}
\hline & Spontaneous occurrence \\
\hline \multirow{4}{*}{ Histopathological characteristics } & Few myofibrils containing central nucleation \\
\hline & Severe myopathy with early necrosis of muscle fibers \\
\hline & Muscle regeneration associated with connective tissue proliferation in endomysium and perimysium \\
\hline & Ventricular dilation and thinning of the myocardium due to replacement by fibrous tissue \\
\hline \multirow{2}{*}{ Phenotypic characteristics } & Equivalent body mass as adults \\
\hline & Lumbar kyphosis and lordosis \\
\hline \multirow{11}{*}{ Clinical manifestations } & Progressive muscle weakness \\
\hline & Muscle atrophy \\
\hline & Joint Contractures \\
\hline & Hypersalivation and dysphagia \\
\hline & Life expectancy approximately $25 \%$ of normal \\
\hline & Development of muscular contractures with development of lumbar kyphosis and lordosis \\
\hline & Abnormalities in gait diagnosed early \\
\hline & Contraction injuries \\
\hline & Cardiac arrhythmias \\
\hline & Respiratory function impairment \\
\hline & Death due to cardiorespiratory insufficiency at approximately 3 years \\
\hline \multicolumn{2}{|l|}{ GRDM - Early diagnosis } \\
\hline \multicolumn{2}{|r|}{ Increased CK in the first days of life (peak 6-8 weeks) } \\
\hline \multicolumn{2}{|r|}{ Development of secondary lesions at 2 months } \\
\hline \multicolumn{2}{|r|}{ Changes in gait and posture occur between $6-10$ weeks } \\
\hline \multicolumn{2}{|r|}{ Early signs of arrhythmias at 6 months } \\
\hline \multicolumn{2}{|r|}{ Severe cardiomyopathy with signs of HF at 2 years } \\
\hline & CK Creatine kinase; HF Heart failure. \\
\hline
\end{tabular}

lesions could be in the uterus, which could allow for earlier diagnosis of the disease (VALENTINE et al., 1988; NGUYEN et al., 2002; COLLINS \& MORGAN, 2003). However, the high mortality rate observed in GRMD during the first 2 weeks of life coinciding with a high CK concentration suggested that DGR puppies could develop massive muscular necrosis mainly of the respiratory muscles (NGUYEN et al., 2002; COLLINS \& MORGAN, 2003). CK levels remain elevated during the advanced stage of the disease, indicating persistent muscle fiber necrosis, but a progressive decline in these levels is observed in dogs aged 3-and-a-half to 6 years, similar to that seen in patients with DMD (VALENTINE et al., al., 1988). Dogs that survive during the neonatal period will present intermittent cycles of muscular degeneration and necrosis with sufficient initial regeneration, to compensate for fibers degeneration (Valentine et al., 1990; NGUYEN et al., 2002 ; BANKS \& CHAMBERLAIN, 2008).

Pathogenesis of muscular dystrophy can be divided into two phases: phase I involves the direct effects of dystrophin deficiency, and phase II is related to endomysial fibrosis and muscular atrophy (HOFFMAN \& GORSOSPE, 1991; NGUYEN et al., 2002). Phase I lesions are reported in all species lacking dystrophin (humans, mice, dogs and cats) and are characterized by hyalinization, hypertrophy, intracellular accumulation of calcium salts and necrosis with subsequent regeneration of myofibers to compensate degeneration, in addition to the expressive inflammatory response (NGUYEN et al., 2002; MIYAZATO et al., 2011a; MIYAZATO et al., 2011b). Phase II lesions can be observed in DGR dogs at 2 months of age, and consist of increased endomysial connective tissue (endomysial fibrosis) and replacement of muscle fibers by fibrous tissue and adipose cells. In addition, marked muscle atrophy, complete mineralization of the foci of myofibers, and heterogeneity of fiber diameter are also observed in muscles in phase II of the disease. Only children with DMD, DGR dogs and diaphragms of mdx mice present this stage of the disease. Moreover, the DGR dog is the only animal model that shows (early at 2 months) the widespread development of secondary lesions due to dystrophin deficiency in a manner 
compatible with human boys with DMD (NGUYEN et al., 2002; BANKS \& CHAMBERLAIN, 2008; LESSA et al., 2014). The major ultrastructural findings in DGR dogs included dilatation of the sarcoplasmic reticulum, hypercontracted fibers, necrosis, degeneration of subsarcolemmal areas, and cytoplasmic disorganization (VALENTINE et al., 1990).

A study involving 16 male golden retriever dogs deficient in dystrophin aged five to 51 months showed, in the histopathological analysis, the presence of hyalinization and necrosis of muscle fibers as well as an increase of inflammatory cells, particularly mononuclear cells. In addition, variations in fiber size, dystrophic calcification, regeneration of fibers of smaller diameter and infiltration of adipose cells were observed in the interfascicular areas. There was also a significant increase in the number of positive fibers for calcium deposition in the skeletal muscles of these dogs, suggesting that the disruption of calcium homeostasis is associated with the severe degenerative lesions observed in these animals. Furthermore, histological evaluation of the skeletal muscle fibers of DGR dogs evidenced irregular shape and loss of the mosaic pattern among the different types of muscle fibers. In this study, cardiac involvement with pronounced lesions was also observed in $87.5 \%$ of the DGR analyzed. Analysis of the cardiac muscle of these dystrophic dogs revealed increased connective tissue deposition, presence of inflammatory cells, necrosis and some fibers with dystrophic calcification (MIYAZATO et al., 2011a; MIYAZATO et al., 2011b). The DGR animals aged 10 to 20 months of age presented deposition of fibrous and adipose tissue in extensive areas of the left and right ventricles, which compromises correct functioning of heart, progressing to heart failure (MALVESTIO et al., 2015).

Recently, in a histopathological, biochemical and immunological study carried out on the gastrocnemius muscle and myotendinous junction of DGR animals, similar alterations to those observed in humans affected by muscular dystrophy were observed, such as fibrosis, hyalinization, hypertrophy, necrosis, calcification and regeneration. However, lesions morphology in the myotendinous junctions was more pronounced than those of the gastrocnemius muscle, possibly due to the increase in Type II fibers, decreased MHCI complex expression, and decreased cytotoxic activity of CD8 cells. Such results strongly suggested that the immune system acts on the inflammatory process in DMGR (BERETTA et al., 2014).
Clinical aspects of the disease in the DGR dog

Clinical manifestations in DGR dogs are progressive, with a gradual loss of muscle mass and development of contractures that often lead to skeletal deformities (COOPER et al., 1988; SHELTON \& ENGVALL，2005; NAKAMURA \& TAKEDA, 2011). Extensive muscle degeneration and generalized necrosis are identified soon after birth (VALENTINE et al., 1988; NAKAMURA \& TAKEDA, 2011). Clinical weakness and gait abnormalities are the first manifestations in puppies affected by DMD at 6 to 10 weeks old, similar to that observed in DMD children who exhibit their first clinical signs at 2 to 4 years old (VALENTINE et al., 1988). A notable feature in DGR dogs is the enlargement of the base of the tongue due to hypertrophy and muscle pseudohypertrophy, which leads to pharyngeal and esophageal dysfunction, resulting in dysphagia, salivation, regurgitation, and finally, aspiration pneumonia (VALENTINE et al., 1988; NAKAMURA \& TAKEDA, 2011; KORNEGAY et al., 2012). Progressive gait impairment is evidenced in DGR dogs by the sixth week of age as a result of atrophy of trunk and temporalis muscles, plantar posture due to overextension at the carpus, overflexion at the tarsus and abduction of the paws, as well as progressive lumbar kyphosis and consequent lordosis (VALENTINE et al., 1988; SHELTON \& ENGVALL, 2005; NAKAMURA \& TAKEDA, 2011; KORNEGAY et al., 2012). In addition, the affected dogs present muscular atrophy, weakness and greater susceptibility to injury induced by contraction (NGUYEN et al., 2002; BANKS \& CHAMBERLAIN, 2008). Cardiomyopathy is often observed in young DGR dogs. In the ECG evaluation, these animals present ventricular arrhythmias and increase in $\mathrm{Q} / \mathrm{R}$ space at six months of age, which progress with age (MOISE et al., 1991). Moreover, increased echogenicity corresponding to the areas of mineralization at necropsy are observed on the echocardiogram at 6-and-a-half months of age. Ventricular dilatation and myocardial thinning due to fibrous tissue replacement, with decreased myocardial contractile function, are frequent findings in DGR dogs at 2 years of age (MOISE et al., 1991). As in patients with DMD, impairment of respiratory function is also demonstrated in DGR dogs and, together with cardiomyopathy, is the main cause of death in these animals (VALENTINE et al., 1989; COLLINS \& MORGAN, 2003; BANKS \& CHAMBERLAIN, 2008; NAKAMURA \& TAKEDA, 2011). It was demonstrated that homozygous (carrier) females and small dogs affected could have milder clinical signs and only some histological lesions seen in male DGR (VALENTINE et al., 1988. KORNEGAY et al., 2012). A previous 
study documented that mixed breed DGR-labrador retriever dogs could have a less severe histopathological phenotype of the disease, as evidenced by the degree of necrosis and differentiation of muscle fibers, supporting the idea that cross-breeding could reduce disease severity (MIYAZATO et al., 2011c).

\section{Advances in DMD therapy using GRMD}

The therapeutic strategies used for DMD can be categorized as pharmacological, molecular, cellular or a combination of them. Table 3 summarizes the therapeutic techniques already used in dogs. Pharmacological therapies aim to control pathogenic mechanisms, seeking to ameliorate the dystrophic phenotype of the disease. The two most common molecular approaches are gene therapy, in which the dystrophin gene is introduced into the muscle by local injection, or through the vasculature using plasmids or viral vectors, and genetic correction, involving the introduction of oligonucleotides to restore the correct nucleotide sequence. Regarding such cell-based therapies, the approach could be through transplantation of normal cells such as myoblasts or stem cells into the diseased muscle (KORNEGAY et al., 2012).
Genome editing therapy is based on an RNA strands that guide a nuclease enzyme to cut the DNA at a precise point in the genome, which is the site of the defective exon. Cells, then, repair the vacant space by assembling the broken strands, or by using a DNA template provided to create a new sequence (KAISER, 2016). Several studies have demonstrated the effectiveness of TALENs (Transcription Activator-Like Effector Nuclease) and CRISPR (Clustered Regularly Interspaced Short Palindromic Repeat) in studies of gene repair in induced pluripotent stem cells (iPSCs). The CRISPR technique is an extremely accurate genome-editing technique with very promising results. CRISPRCas9 technology has already been used in the correction of the mutant dystrophin gene in mice, avoiding the development of muscular dystrophy, and also in the repair of cystic fibrosis transmembrane receptor locus by homologous recombination in cultured intestinal stem cells from human patients with this disease (WU et al., 2013). LI et al. (2015) performed the genetic correction of the gene that causes muscular dystrophy in humans and obtained promising results with three different techniques, demonstrating that the CRISPR technique was

Table 3 - Summary of muscular dystrophy therapies used in dogs.

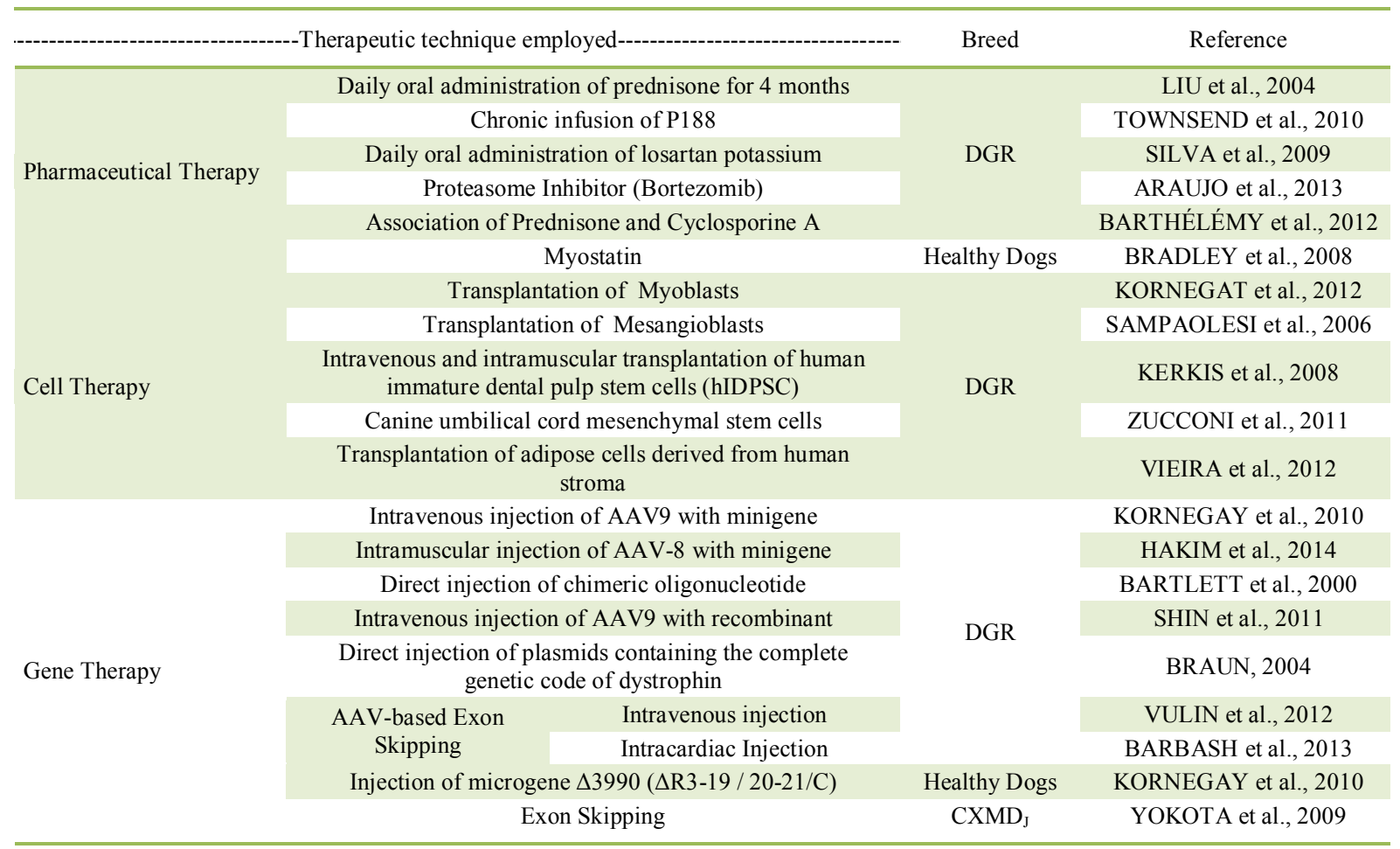

Ciência Rural, v.47, n.10, 2017. 
equally effective in the TALEN technique and that both obtained minimal mutagenic effects outside the initial target when directed to a single sequence region. The method was considered accurate and efficient with very promising prospects.

Subsequently, MAGGIO et al. (2016) obtained promising results using viral vectors to correct mutations in the dystrophin gene with CRISPR-Cas9 associated or not with TALENs in cultures of progenitor muscle cells derived from $\mathrm{mdx}$ mice. The authors were able to correct the mutation in the dystrophin gene in up to $37 \%$ of the cell population evaluated. Likewise, BENGTSSON et al. (2017) reported a significant increase in the expression of dystrophin with an increase in the functional capacity of the muscle fibers of $\mathrm{mdx}^{4 \mathrm{cv}}$ mice.

Many studies in DGR dogs have been conducted to evaluate the role of pharmacological therapies for the treatment of DMD. Functional and histopathological changes were evaluated in DGR dogs submitted to a daily oral administration of prednisone for four months. Results showed hypertrophy of the cranial sartorius muscle, an improvement of the tibiotarsal joint angulation, increased calcification of myofibers, and decreased fetal myosin expression. These findings show the benefits, but also deleterious histopathological alterations, in these animals after treatment with prednisone (LIU et al., 2004). Another study demonstrated that chronic infusion of a membranesealing poloxamer, P188, reduced myocardial fibrosis of DGR dogs, prevented serum increase of cardiac troponin I (cTnI) and atrial natriuretic peptide (ANP), and prevented left ventricular remodeling. These findings have important clinical relevance because P188 could act as a therapeutic strategy for dystrophic cardiomyopathy, which is the second most common cause of death in patients with DMD (TOWNSEND et al., 2010). In DMD patients, losartan potassium is used as an anti-fibrosis treatment because of its inhibition of TGF-beta due to the fact that it is an angiotensin inhibitor, and DMD patients may often present with increased levels of potassium, urea and creatinine. However, the use of losartan potassium in DGR administered orally at a dose of 50mg for nine weeks did not influence renal function, serum potassium level or blood pressure (SILVA et al., 2009).

Another study showed that DGR dogs treated with bortezomib, a proteasome inhibitor, presented greater uniformity of fiber diameter and decreased lymphocyte invasion, suggesting attenuation of the inflammatory process and a reduction of $t$ connective tissue deposit in the endomysium and perimysium of the muscle fibers.
Also, increased $\alpha$ - and $\beta$-dystroglican expression was also reported, which indicates an improvement in the histopathological phenotype of the disease. These results suggested that bortezomib could block the activation of phospho-NFkB, which could be important in the pathogenesis of DMD and possibly represent a line of research in DMD therapy (ARAUJO et al., 2013).

More recently, the role of the combination of cyclosporin A and prednisolone at immunosuppressive levels in the course of the disease of DGR dogs has been verified. Results showed an intense effect on the DGR phenotype after treatment, leading to exacerbation of calcification lesions, atrophy, decreased muscle strength and increased fatigue. However, there was a remarkable improvement in disease progression at the systemic level and in animals' locomotion, as well as a decrease in $\mathrm{CK}$ values. This fact emphasizes the interest of a multiparametric evaluation in the canine model of DMD, which could reproduce the complexity of the human disease (BARTHÉLÉMY et al., 2012). Another study suggested that for effective immunosuppressive treatment in dogs, the dosage of ciclosporin A requires adjustments in the course of therapy, guided by serum values and the animals age (MORINI et al., 2008).

Three four-day-old DGR dogs submitted to intravenous injection with an adenovirus-associated vector (AAV9) carrying a human codon with dystrophin minigene under the control of the cytomegalovirus (CMV), presented generalized muscle transgene expression after 16 weeks of treatment (KORNEGAY et al., 2010). In DGR dogs, the point of the mutation is within intron 6 , and this leads to the deletion of exon 7 in the dystrophin mRNA, with a resulting frameshift caused by the early termination of the translation. Direct injection of the chimeric oligonucleotide into the cranial tibial muscle of a 6-week-old affected male dog resulted in repair of the dystrophin mutation site after 48 weeks of treatment (BARTLETT et al., 2000). Also, affected dogs treated by transendocardial route with an adenoviral vector carrying a recombinant to correct the mutation site in exons 6 and 8 and thus reestablish the dystrophin protein sequence in the hearts of affected dogs, presented restoration of cardiac dystrophin expression at 13 months as confirmed by reverse transcriptase-PCR (RT-PCR). This finding was accompanied by an improvement in cardiac function and a reduction of fibrosis, both verified by magnetic resonance imaging (MRI) (BISH et al., 2012).

Regarding cell-based therapies, it is known that various cell types such as adult, fetal and embryonic stem cells can contribute to the regeneration of diseased muscle. However, it was 
reported that canine myoblast transplantation proved to be incapable of achieving significant implantation in DGR dogs (KORNEGAY et al., 2012). Conversely, transplantation of mesangioblasts (stem cells associated with vessels) in DGR dogs resulted in a great recovery of dystrophin expression and in the reestablishment of muscular morphology and function (confirmed by the measurement of the contraction force of the individual fibers), which allowed for a remarkable clinical improvement and preservation of motor activity (SAMPAOLESI et al., 2006). Another study evaluating the human immaturedental pulp stem cells (hIDPSC) transplanted by arterial or muscular injection in four DGR dogs showed minimal expression of dystrophin in treated animals. However, improvement in clinical status was observed in animals who received monthly arterial injections, suggesting that multiple systemic deliveries could be more efficient than local injections (KERKIS et al., 2008). In this context, mesenchymal stem cells derived from the canine umbilical cord were identified in the dystrophic muscle after its systemic administration. However, the expression of dystrophin was not detected in the animals after transplantation. Results showed that umbilical cord mesenchymal stem cells could be able to reach the animal's musculature, but would not be able to reach full differentiation in skeletal muscle cells (ZUCCONI et al., 2011). More recently, it has been reported that adipose cells derived from human stroma, when injected systemically into the dog's cephalic vein, could have the ability to penetrate, implant and express the dystrophin in the dystrophic muscle of the DGR up to 6 months after transplantation. Thus, introduction of large numbers of human mesenchymal cells into a large animal model without immunosuppression is a safe procedure that may have significant implications for future therapy in patients with DMD (VIEIRA et al., 2012).

\section{CONCLUSION}

Despite progress made in understanding the genetics and pathogenesis of DMD, the cure for the disease, which has a 100\% mortality rate, has not yet been established. Possibly, this failure could be explained by the fact that most of even the current research is still being performed on murine models that do not reliably reproduce the pathogenesis of the disease. The canine GRMD model is undoubtedly the closest to the human disease, presenting severe cardiac and skeletal alterations similar to those observed in those affected by DMD. Therefore, GRMD animals are extremely useful for a better understanding of pathological mechanisms and for pre-clinical studies recently developed using pharmacological, genetic and cell-based therapies to seek cures or to increase life expectancy of those affected by DMD.

\section{ACKNOWLEDGEMENTS}

I. M. Martins was supported by Coordenação de Aperfeiçoamento de Pessoal de Nível Superior (CAPES). This work was partially supported by Fundação de Amparo à Pesquisa do Estado de São Paulo (FAPESP), Grant number 13/25957-6.

\section{REFERENCES}

ALLAMAND, V.; CAMPBELL, K.P. Animal models for muscular dystrophy: valuable tools for the development of therapies. Human Molecular Genetics, v.9, p.2459-2467, 2000. Available from: $<$ http://hmg.oxfordjournals.org/content/9/16/2459.full.pdf + html $>$. Accessed: Apr. 21, 2016. doi: 10.1093/hmg/9.16.2459.

ARAUJO, K.P. et al. Bortezomib (PS-341) treatment decreases inflammation and partially rescues the expression of the dystrophinglycoprotein complex in GRMD dogs. PLoS One, v.8, p.e61367, 2013. Available from: <http://journals.plos.org/plosone/article/ asset?id=10.1371\%2Fjournal.pone.0061367.PDF $>$. Accessed: Apr. 21, 2016. doi: 10.1371/journal.pone.006137.

BALTZER, W.I. et al. Dystrophin-deficient muscular dystrophy in a Weimaraner. Journal of the American Animal Hospital Associaton, v.43, p.227-232, 2007. Available from: <http://jaaha. org/doi/pdf/10.5326/0430227>. Accessed: Apr. 21, 2016. doi: http://dx.doi.org/10.5326/0430227.

BANKS, G.B.; CHAMBERLAIN J.S. The value of mammalian models for duchenne muscular dystrophy in developing therapeutic strategies. Current Topics in Developmental Biology, v.84, p.431-453, 2008. Available from: <http://www.sciencedirect. com/science/article/pii/S0070215308006091>. Accessed: Apr. 21, 2016. doi: 10.1016/S0070-2153(08)00609-1.

BARBASH, I.M. et al. MRI roadmap-guided transendocardial delivery of exon-skipping recombinant adeno-associated virus restores dystrophin expression in a canine model of Duchenne muscular dystrophy. Gene Therapy, v.20, p.274-282, 2013. Available from: <https://www.ncbi.nlm.nih.gov/pmc/articles/ PMC3424392/pdf/nihms367470.pdf>. Accessed: Jun. 23, 2017. doi: $10.1038 /$ gt.2012.38.

BARTHÉLÉMY, I. et al. Effects of an immunosuppressive treatment in the GRMD dog model of Duchenne muscular dystrophy. PLoS One. 7:e48478, 2012. Available from: <http:// journals.plos.org/plosone/article/asset?id=10.1371\%2Fjournal. pone.00,8478.PDF>. Accessed: Apr. 21, 2016. doi: 10.1371/ journal.pone.0048478.

BARTLETT, R.J. et al. In vivo targeted repair of a point mutation in the canine dystrophin gene by a chimeric RNA/DNA oligonucleotide. Nature Biotechnology, v.18, p.615-622, 2000. Available from: <http://www.nature.com/nbt/journal/v18/n6/full/ nbt0600_615.html >. Accessed: Apr. 21, 2016. doi: 10.1038/76448.

BENGTSSON, N.E. et al. Muscle-specific CRISPR/Cas9 dystrophin gene editing ameliorates pathophysiology in a mouse model for Duchenne muscular dystrophy. Nature Communications, n.14454, p.1-9, 2017. Available from: <http:// 
www.nature.com/articles/ncomms14454>. Accessed: Mar. 16, 2016. doi: $10.1038 /$ ncomms 14454 .

BERETTA, D.C. et al. Immunohistochemical and Morphometric Evaluation of gastrocnemius muscle and myotendinous junction of Golden Retriever dogs with muscular dystrophy. Brazilian Journal of Veteriary Pathology, v.7, p.70-81, 2014. Available from: <http://bjvp.org.br/wp-content/uploads/2015/07/ DOWLOAD-FULL-ARTICLE-2 $208812014 \quad 7 \quad 31 \quad 12 \quad 46 . p d f>$. Accessed: Apr. 21, 2016.

BERGMAN, R.L. et al. Dystrophin-deficient muscular dystrophy in a Labrador retriever. Journal American Animal Hospital Associaton, v.38, p.255-261, 2002. Available from: <http:// vetneuromuscular.ucsd.edu/publications/dystrophin.pdf> Accessed: Apr. 21, 2016. doi: 10.5326/0380255.

BISH, L.T. et al. Long-term restoration of cardiac dystrophin expression in golden retriever muscular dystrophy following rAAV6-mediated exon skipping. Molecular Therapy, v.20, p.580589, 2012. Available from: <http://www.nature.com/mt/journal/ v20/n3/full/mt2011264a.html>. Accessed: Apr. 21, 2016. doi 10.1038/mt.2011.264.

BOGDANOVICH, S. et al. Therapeutics for Duchenne muscular dystrophy: current approaches and future directions. Journal of Molecular Medicine, v.82, p.102-115, 2003 Available from: <http://journals.plos.org/plosone/article/ asset?id=10.1371\%2Fjournal.pone.0048478.PDF>. Accessed: Apr. 21, 2016. doi:10.1007/s00109-003-0484-1.

BRADLEY, L. et al. Myostatin as a therapeutic target for musculoskeletal disease. Cellular and Molecular Life Science, v.65, p.2119-2124, 2008. Available from: <https://link.springer. com/article/10.1007\%2Fs00018-008-8077-3>. Accessed: Jun. 26 , 2017. doi: 10.1007/s00018-008-8077-3.

BRAUN, S. Naked plasmid DNA for the treatment of muscular dystrophy. Current Opinion in Molecular Therapeutics, v.6, p.499-505, 2004

BULFIELD, G. et al. X chromosome-linked muscular dystrophy $(\mathrm{mdx})$ in the mouse. Proceedings of the National Academy of Science, v.81, p.1189-1192, 1984. Available from: <http://www. pnas.org/content/81/4/1189.long $>$. Accessed: Apr. 21, 2016. doi: 10.1073/pnas.81.4.1189.

COLLINS, C.A.; MORGAN, J.E. Duchenne's muscular dystrophy: animal models used to investigate pathogenesis and develop therapeutic strategies. International Journal of Experimental Pathology, v.84, p.165-172, 2003. Available from: <http:// onlinelibrary.wiley.com/doi/10.1046/j.1365-2613.2003.00354.x/ pdf>. Accessed: Apr. 21, 2016. doi: 10.1046/j.13652613.2003.00354.x.

COOPER, B.J. et al. The homologue of the Duchenne locus is defective in X-linked muscular dystrophy of dogs. Nature, v.334, p.154-156, 1988. Available from: <http://www.nature.com/nature/ journal/v334/n6178/abs/334154a0.html>. Accessed: Apr. 21, 2016. doi: $10.1038 / 334154 \mathrm{a} 0$.

DECONINCK, N.; DAN, B. Pathophysiology of Duchenne muscular dystrophy: current hypotheses. Pediatric Neurology, v.36, p.1-7, 2007. Available from: $<$ http://ac.els-cdn.com/S $0887899406006242 / 1$-s2.0 S0887899406006242-main.pdf? tid=280c8c12-07ed-
11 e $6-9210-00000$ a acb $35 \mathrm{f} \& \mathrm{acdnat}=1461262764$ dae 2 df5 5 cb005f 27 fbff6bed4b6866d6 $>$. Accessed: Apr. 21, $201 \overrightarrow{6}$. doi: 10.1016/j.pediatrneurol.2006.09.016.

HAKIM, C.H. Systemic gene transfer reveals distinctive muscle transduction profile of tyrosine mutant AAV-1, - 6 , and -9 in neonatal dogs. Molecular Therapy, v.1, p.14002, 2014. Available from: <http://www.sciencedirect.com/science/article/ pii/S2329050116300857>. Accessed: May 30, 2016. doi: 10.1038/ $\mathrm{mtm} .2014 .2$.

HOFFMAN, E.P.; GOROSPE, J.R.M. The animal models of Duchenne muscular dystrophy: windows on the pathophysiological consequences of dystrophin deficiency. In: MORROW, J.S.; MOOSEKER, M.S. Current topics in membranes. New York: Academic, 1991. V.38, p.113-154

HOWELL, J.M. et al. The fulminating neonatal form of expression in the golden retriever dog model of Duchenne muscular dystrophy. In: INTERNATIONAL CONGRESS ON NEUROMUSCULAR DISEASES, 8, 1994, New York, USA. American Association of Electrodiagnostic Medicine, Suppl.1, p.S182, 1994.

KASPAR, R.W. et al. Current understanding and management of dilated cardiomyopathy in Duchenne and Becker muscular dystrophy. Journal of the Americam Association of Nurse Practitioners, v.21, p.241-249, 2009. Available from: <http:/ www.ncbi.nlm.nih.gov/pmc/articles/PMC3690667/pdf/ nihms-466517.pdf $>$. Accessed: Apr. 21, 2016. doi: 10.1111/j.17457599.2009.00404.x.

KERKIS, I. et al. Early transplantation of human immature dental pulp stem cells from baby teeth to golden retriever muscular dystrophy (GRMD) dogs: Local or systemic? Journal of Translational Medicine, v.6, p.1-13, 2008. Available from: <http:// www.ncbi.nlm.nih.gov/pmc/articles/PMC2529267/pdf/14795876-6-35.pdf $>$. Accessed: Apr. 21, 2016. doi: 10.1186/14795876-6-35.

KORNEGAY, J.N. et al. Canine models of Duchenne muscular dystrophy and their use in therapeutic strategies. Mammalian Genome, v.23, p.85-108, 2012. Available from: <http://www.ncbi. nlm.nih.gov/pmc/articles/PMC3911884/pdf/nihms481588.pdf>. Accessed: Apr. 21, 2016. doi: 10.1007/s00335-011-9382-y.

KORNEGAY, J.N. et al. Widespread muscle expression of an AAV9 human mini-dystrophin vector after intravenous injection in neonatal dystrophin-deficient dogs. Molecular Therapy, v.18, p.1501-1508, 2010. Available from: <http://www.ncbi.nlm.nih. gov/pmc/articles/PMC2927072/pdf/mt201094a.pdf>. Accessed: Apr. 21, 2016. doi: 10.1038/mt.2010.94.

LESSA, T.B. et al. Laparoscopic guided local injection in the X-linked muscular dystrophy mouse (mdx) diaphragm. An advance in experimental therapies for Duchenne Muscular Dystrophy. Acta Cirurgica Brasileira, v.29, p.715-720, 2014. Available from: <http://www.scielo.br/pdf/acb/v29n11/01028650-acb-29-11-00715.pdf $>$. Accessed: Apr. 21, 2016. doi: 10.1590/S0102-86502014001800004>.

LI, H.L. Precise correction of the Dystrophin gene in duchenne muscular dystrophy patient induced pluripotent stem cells by TALEN and CRISPR-Cas9. Stem Cell Reports, v.4, p.143-154, 2015. Available from: <http://www.sciencedirect.com/science/ article/pii/S221367111400335X >. Accessed: Feb. 14, 2017. doi: 10.1016/j.stemcr.2014.10.013 
LIU, J.M. et al. Effects of prednisone in canine muscular dystrophy. Muscle and Nerve, v.30, p.767-773, 2004. Available from: <http:// onlinelibrary.wiley.com/doi/10.1002/mus.20154/pdf>. Accessed: Apr. 21, 2016. doi: 10.1002/mus.20154.

MAGGIO, I. et al. Selection-free gene repair after adenoviral vector transduction of designer nucleases: rescue of dystrophin synthesis in DMD muscle cell populations. Nucleic Acids Research, v.44, n.3, p. 1449-1470, 2016. Available from: <https://www.ncbi.nlm. nih.gov/pmc/articles/PMC4756843/pdf/gkv1540.pdf>. Accessed: Jun. 26, 2017. doi: 10.1093/nar/gkv1540.

MALVESTIO, L.M.M. et al. Histopathologic evolution of cardiomyopathy in a canine model of duchenne muscular dystrophy. Journal of Advanced Veterinary Research, v.5, p.121-126, 2015. Available from: <http://www.advetresearch.com/ index.php/AVR/article/view/54/52>. Accessed: Jun. 26, 2017.

MIYAZATO, L.G. et al. Evaluation of intracellular calcium in Golden Retriever muscular dystrophy. Brazilian Journal Veterinary Pathology, v.4, p.95-102, 2011a. Available from: $<$ http://bjvp.org.br/wp-content/uploads/2015/07/DOWNLOADFULL-ARTICLE-18-20881_2011_7_5_37_27.pdf \$. Accessed: Apr. 21, 2016.

MIYAZATO, L.G. et al. Involvement of organic systems in golden retriever X-linked muscular dystrophy. Brazilian Journal Veterinary Pathology, v.4, p.87-94, 2011b. Available from: $<$ http://bjvp.org.br/wp-content/uploads/2015/07/DOWNLOADFULL-ARTICLE-17-20881_2011_7_5_36_35.pdf >. Accessed: Apr. 21, 2016.

MIYAZATO, L.G. et al. Muscular dystrophy in dogs: does the crossing of breeds influence disease phenotype? Veterinary Pathology, v.48, p.655-662, 2011c. Available from: <http://vet. sagepub.com/content/48/3/655.full.pdf $>$. Accessed: Apr. 21, 2016. doi: $10.1177 / 0300985810387070$

MOISE, N.S. et al. Duchenne's cardiomyopathy in a canine model: electrocardiographic and echocardiographic studies. Journal of the American College Cardiology, v.17, p.812-820, 1991. Available from: <http://ac.els-cdn.com/S0735109710802025/1s2.0-S0735109710802025main.pdf?_tid=935444d4-07e2-11e6-aa b700000aab0f01\&acdnat $=1461258219 \quad 58 \mathrm{~d} 5762 \mathrm{a} 9085 \mathrm{e} 44358 \mathrm{e}$ 9940f640d4a60>. Accessed: Apr. 21, 2016. doi: 10.1016/S07351097(10)80202-5.

MORINI, A.C. et al. Análise das dosagens e concentrações séricas da ciclosporina A em cães da raça Golden Retriever normais ou afetados pela distrofia muscular. Brazilian Journal of Veterinay Research and Animal Science, v.45, p.131-137, 2008. Available from: <http://www.revistas.usp.br/bjvras/article/ view/26710/28493>. Accessed: Apr. 25, 2016. doi: 10.1590/ S1413-95962008000200008.

NAKAMURA, A.; TAKEDA, S. Mammalian models of Duchenne Muscular Dystrophy: pathological characteristics and therapeutic applications. Journal of Biomedicine and Biotechnology, v.2011, p.1-8, 2011. Available from: <http://www.ncbi.nlm.nih.gov/pmc/ articles/PMC3022202/pdf/JBB2011-184393.pdf>. Accessed: Apr. 21, 2016. doi: 10.1155/2011/184393.

NGUYEN, F. et al. Muscle lesions associated with dystrophin deficiency in neonatal Golden Retriever puppies. Journal of Comparative Pathology, v.126, p.100-108, 2002. Available from: <http://ac.els-cdn.com/S0021997501905262/1-s2.0-
S0021997501905262main.pdf?_tid=19c8ebd4-07f0-11e6b9e500000aacb35f\&acdnat $=1461264028$ 0f $26 \mathrm{c} 690 \mathrm{~d} 68 \mathrm{ba} 5$ 55371e02dc20589616>. Accessed: Apr. 21, 2016. doi: 10.1053/ jсpa.2001.0526.

SAMPAOLESI, M. et al. Mesoangioblast stem cells ameliorate muscle function in dystrophic dogs. Nature, v.444, p.574-579, 2006. Available from: <http://www.nature.com/nature/journal/ v444/n7119/abs/nature05282.html>. Accessed: Apr. 21, 2016. doi: 10.1038/nature 05282

SCHATZBERG, S.J. et al. Molecular analysis of a spontaneous dystrophin 'knockout' dog. Neuromuscular Disorders, v.9, p.289-295, 1999. Available from: <http://ac.els-cdn.com/ S0960896699000115/1-s2.0-S0960896699000115-main.pdf? tid=810fef $18-07 \mathrm{f} 0-11$ e6-9972-00000aab0f01 \&acdnat $=1461264$ 202 97de9c63baabe481eb97cf8fa8d38d19>. Accessed: Apr. 21, 2016. doi: 10.1016/S0960-8966(99)00011-5.

SHARP, N.J.H. et al. An error in dystrophin mRNA processing in golden retriever muscular dystrophy, an animal homologue of Duchenne muscular dystrophy. Genomics, v.13, p.115-121, 1992. Available from: <http://ac.els-cdn. com/088875439290210J/1-s2.0 088875439290210J-main.pdf? tid $=$ d823dee2-0b04-11e6-9c22 00000aacb35e\&acdnat $=1461602$ 791_59c592045c1fc5e005ac0020b38f0b09 >. Accessed: Apr. 25, 2016. doi: 10.1016/0888-7543(92)90210-J.

SHELTON, G.D.; ENGVALL, E. Canine and feline models of human inherited muscle diseases. Neuromuscular Disorders, v.15, p.127-138, 2005. Available from: <http://ac.els-cdn.com/S0960896604003116/1-s2.0S0960896604003116-main.pdf? tid=9aafb 3 e $0-07$ f0 11 e 6 - b $240-00000$ a ab 0 f $27 \&$ acd nat $=1461264245$ a65b1b6a882665ba2817d0cc19928813>. Accessed: Apr. 21, $201 \overline{6}$. doi: 10.1016/j.nmd.2004.10.019.

SHELTON, G.D. et al. Muscular dystrophy in female dogs. Journal of Veterinay Internal Medicine, v.15, p.240244, 2001. Available from: <http://onlinelibrary.wiley.com/ doi/10.1111/j.1939-1676.2001.tb02317.x/epdf>. Accessed: Apr. 25, 2016. doi: 10.1111/j.1939-1676.2001.tb02317.x.

SHIMATSU, Y. et al. Canine X-linked muscular dystrophy in Japan (CXMDJ). Experimental Animals, v.52, p.93-97, 2003. Available from: <https://www.jstage.jst.go.jp/article/ expanim/52/2/52_2_93/_pdf $>$. Accessed: Apr. 21, 2016. doi: 10.1538/expanim.52.93.

SHIN, J.H. et al. Humoral immunity to AAV-6, 8, and 9 in normal and dystrophyc dogs. Human Gene Therapy, v. 23, p.287-294, 2011. Available from: <https://www.ncbi.nlm.nih.gov/pmc/articles/ PMC3300072/>. Accessed: Jun. 26, 2017. doi: 10.1089/hum.2011.125.

SILVA, M.B. et al. Influência do bloqueador de receptor de angiotensina (Losartana potássica) na função renal e pressão arterial em cães GRMD. Pesquisa Veterinária Brasileira, v.29, p.322-326, 2009. Available from: <http://www.scielo.br/pdf/pvb/ v29n4/a08v29n4.pdf $>$. Accessed: Apr. 21, 2016.

TOWNSEND, D. et al. Chronic administration of membrane sealant prevents severe cardiac injury and ventricular dilatation in dystrophic dogs. Journal of Clinical Investigation, v.120, p.11401150, 2010. Available from: <http://www.ncbi.nlm.nih.gov/pmc/ articles/PMC2846060/pdf/JCI41329.pdf>. Accessed: Apr. 21, 2016. doi: $10.1172 / \mathrm{JCI} 41329$. 
VALENTINE, B.A. et al. Canine X-linked muscular dystrophy: morphologic lesions. Journal of the Neurological Science, v.97, p.1-23, 1990. Available from: <http://ac.els-cdn.com/0022510X90900955/1-s2.00022510X90900955-main.pdf?_tid=d8ace1bc-07f1-11e6-921100000 aacb35 f\&acdnat $=1461264778$ f32 cacb3 $027661 \mathrm{fbbc} 8$ b9b40849fdff2>. Accessed: Apr. 21, 2016. doi: 10.1016/0022$510 x(90) 90095-5$.

VALENTINE, B.A. et al. Canine X-linked muscular dystrophy. An animal model of Duchenne muscular dystrophy: clinical studies. Journal of the Neurological Science, v.88, p.69-81, 1988. Available from: <http://ac.els-cdn.com/0022510X88902067/1s2.0-0022510X88902067-main.pdf?_tid=72fea494-07f2-11e6$875 \mathrm{e}-00000 \mathrm{aab0f} 26 \&$ acdnat $=1461265037 \mathrm{~d} 5 \mathrm{bcd} 35292 \mathrm{f} 58 \mathrm{~d} 279$ e8f7d29e7bc9956>. Accessed: Apr. 21, 2016. doi: 10.1016/0022510X(88)90206-7.

VALENTINE, B.A. et al. Development of Duchenne-type cardiomyopathy. Morphologic studies in a canine model. American Journal of Pathology, v.135, p.671-678, 1989. Available from: $<$ http://www.ncbi.nlm.nih.gov/pmc/articles/PMC1880020/pdf/ amjpathol00118-0092.pdf>. Accessed: Apr. 21, 2016

VALENTINE, B.A.; COOPER, B.J. Canine X-linked muscular dystrophy: selective involvement of muscles in neonatal dogs. Neuromuscular Disorders, v.1, p.31-38, 1991. Available from: $<$ http://ac.els-cdn.com/096089669190040Y/1-s2.0 096089669190040Y-main.pdf?_tid=14d39ae8-07fa-11e6ab8700000aab0f01\&acdnat $=1461268315 \quad 05 \mathrm{c} 4 \mathrm{a} 9 \mathrm{fd} 41$ bcd0b4e1e129e7eee1719c>. Accessed: Apr. 21, 2016. doi: 10.1016/0960-8966(91)90040-Y.

VIEIRA, N.M. et al. Human adipose-derived mesenchymal stromal cells injected systemically into GRMD dogs without immunosuppression are able to reach the host muscle and express human dystrophin. Cell Transplantation, v.21, p.1407-1417, 2012. Available from: <http://docserver.ingentaconnect.com/ deliver/connect/cog/09636897/v21n7/s7.pdf?expires $=146168291$ $8 \&$ id $=86783449 \&$ titleid $=5476 \&$ accname $=$ UNESP ++ Universidad e+Estadual+Paulista $+\% 27$ Julio + de + Mesquita + Filho $\% 27 \&$ checks um=D29375090238091B352202D27588518>. Accessed: Apr. 21, 2016. doi: $10.3727 / 096368911 X$.

VULIN, A. et al. Muscle function recovery in Golden retriever muscular dystrophy after aav1-u7 exon skipping. Molecular Therapy, v.20, p.2120-2133, 2012. Available from: <https://www. ncbi.nlm.nih.gov/pmc/articles/PMC3498802/>. Accessed: Jun. 26 , 2017. doi: $10.1038 / \mathrm{mt} .2012 .181$.

WALMSLEY, G.L. et al. A Duchenne muscular dystrophy gene hot spot mutation in dystrophin-deficient Cavalier King Charles Spaniels is amenable to exon 51 skipping. PLoS One, v.5, p.e8647, 2010. Available from: <http://journals.plos.org/plosone/article/ asset?id=10.1371\%2Fjournal.pone.0008647.PDF $>$. Accessed: Apr. 21, 2016. doi: 10.1371/journal.pone.0008647.

YOKOTA, T. et al. Efficacy of systemic morpholino exon-skipping in duchenne dystrophy dogs. Annals of Neurology, v.65, p.667676, 2009. Available from: <http://onlinelibrary.wiley.com/ doi/10.1002/ana.21627/abstract; jsessionid=844B7CC8EDD602 C41BF338CF7FDA78F3.f02t03>. Accessed: Jun. 26, 2017. doi: 10.1002/ana. 21627

ZUCCONI, E. et al. Preclinical studies with umbilical cord mesenchymal stromal cells in different animal models for muscular dystrophy. Journal of Biomedicine and Biotechnology, v.2011, p.1-9, 2011. Available from: <http://www.ncbi.nlm.nih.gov/pmc/ articles/PMC3139201/pdf/JBB2011-715251.pdf>. Accessed: Apr. 21, 2016. doi: 10.1155/2011/715251. 